\title{
Church Accountability Perspective in a Tithing Offering (Case Study on the Lumajang Congregation GKJW Church)
}

Elisabet Septiana $^{1 *}$, Whedy Prasetyo ${ }^{1}$, Agung Budi Sulistiyo ${ }^{1}$

${ }^{1}$ Jember University, Faculty of Business and Economics, Jl. Kalimantan No. 37 Sumbersari Jember, Indonesia

DOI: $10.36347 /$ sjebm.2022.v09i01.002

| Received: 08.12.2021 | Accepted: 10.01.2022 | Published: 12.01.2022

*Corresponding author: Elisabet Septiana

Jember University, Faculty of Business and Economics, J1. Kalimantan No. 37 Sumbersari Jember, Indonesia

Abstract

Original Research Article

The purpose of this research is to examine more deeply about the accountability of the church in the offering of tithe at the Lumajang GKJW Church. This research is a qualitative research with a phenomenological approach. Qualitative research is research that intends to understand the phenomenon of what is experienced by the research subject. The results of the analysis found that there were ten dimensions of accountability meaning by the Lumajang GKJW Church Congregation, namely: accountability for tithe offerings as belonging to God, accountability for tithe offerings as an acknowledgment that God is the source of blessings, accountability for tithe offerings as a sign of gratitude and thanks, accountability for tithe offerings as a command. God, accountability for tithe offerings as a form of honesty and obedience to God's commands, accountability for tithe offerings as a sign of love and generosity, accountability for tithe offerings as a sign of faith and trust, accountability for tithe offerings as a responsibility to the church, accountability for tithe offerings as a social responsibility, accountability for offerings tithing as a form of belief in the church. The results of the meaning of the practice of accountability for tithe offerings are interpreted differently in the organization of the Lumajang GKJW Church.

Keywords: Tithe Offering Accountability, Phenomenology, Managing God's Property.

Copyright $(\mathcal{2 0 2 2}$ The Author(s): This is an open-access article distributed under the terms of the Creative Commons Attribution 4.0 International License (CC BY-NC 4.0) which permits unrestricted use, distribution, and reproduction in any medium for non-commercial use provided the original author and source are credited.

\section{INTRODUCTION}

Managing finances, as one of God's blessings, well is an important thing that should be in the life of every congregation. Every congregation needs to realize that their entire life is under the Lordship of Jesus Christ, including money matters, so that the Christian life should have implications for the behavior of the congregation towards wealth and poverty. Therefore, it is not wrong to conclude that a congregation that fails to manage its finances properly means that it fails to carry out God's will in its life. That's why the congregation should pay attention to this and begin to apply the principle of managing their assets properly and honestly so that they are pleasing to God. Jesus himself taught that one of the signs of true spirituality is the right attitude toward money. "Make no store of wealth for yourselves on earth, where it may be turned to dust by worms and weather, and where thieves may come in by force and take it away. But make a store for yourselves in heaven, where it will not be turned to dust and where thieves do not come in to take it away (Matthew, 6:1920)." Giving is an important aspect of ministry and in the spiritual life of the congregation. Although Christian ministry is not just about giving money but is broader than that, true service also involves giving to God.
Giving for services is one aspect of managing finances well. God has a purpose when He entrusts blessings to His people, namely so that His people can take part in ministry and become channels of blessing for others. In the Old Testament Bible, Malachi 3:10-11, it reads:

"Let your tenths come into the store-house so that there may be food in my house, and put me to the test by doing so, says the Lord of armies, and see if I do not make the windows of heaven open and send down such a blessing on you that there is no room for it. And on your account I will keep back the locusts from wasting the fruits of your land; and the fruit of your vine will not be dropped on the field before its time, says the Lord of armies."

That the tithe is used for the maintenance of the temple of God and also to provide welfare for the worshipers in the temple. So in the Book of Malachi God reminds His people that they should offer tithes consistently and consistently. Tithe offerings are usually the core of the church's financial income in addition to income from other offerings from members of the congregation. The tithe from the congregation to God actually belongs to God. 
The results of research conducted by Patty and Irianto (2013) at the GPM Bethel Jemaat Allang church found eight results of the meaning of tithe accountability, including: tithing as belonging to God, tithing as a sign of gratitude and gratitude, tithing as a mandate or command, tithing as a sign of gratitude and thanksgiving. a sign of confession, tithing as a sign of love and generosity, tithing as a sign of faith and trust, tithing as one's responsibility to the church, tithing as a social responsibility to those in need.

As God's church, GKJW Lumajang Congregation always tries to fulfill its vocation as well as possible. GKJW Lumajang congregation was called and sent by God to participate in carrying out His plan of work in this world. GKJW Lumajang congregation was called and sent by God to be responsible for the implementation of God's plan of work in the implementation of love, truth, justice, peace for the community, nation and state. At the Lumajang GKJW Church, every adult has duties and vocations, including in the fields of theology, fellowship, testimony, service, and stewardship. The duties and vocations of the members of the congregation in the field of stewardship are to be responsible for providing the necessary resources, funds and facilities for the implementation of all church service activities.

GKJW Lumajang Jama'at has funds, among others, from community offerings, rewards from the use of GKJW Lumajang Jamaat's property and other rewards, donations and assistance from third parties, as well as from efforts that do not conflict with beliefs and callings. GKJW Lumajang Congregation. Church finances are obtained from offerings from members of the congregation. In general, these offerings come from worship services, monthly, seasonal, annual offerings and so on.

The main source of church finances is community offerings, so that awareness and responsibility for the community must be raised to provide the necessary resources, funds and facilities for the overall implementation of the congregation's service activities accompanied by the best possible guidance. The members of the Lumajang GKJW congregation consist of various ethnic groups, social strata, and different educational backgrounds, so that the tithe offering which is a form of accountability for the members of the congregation to God as the Head of the Church, is interpreted differently by the members of the congregation at the Lumajang GKJW church.

\section{LITERATURE REVIEW \\ 2.1 Foundation Concept}

According to Law no. 16 of 2001 concerning Foundations, foundations are legal entities consisting of separated assets and are intended to achieve certain goals in the social, religious and humanitarian fields. Foundations can carry out business activities to support the achievement of goals and objectives by establishing a business entity and/or participating in a business entity. However, the foundation does not only prioritize profit or pursue/seek profit and/or income as much as possible. The main characteristics of non-profit organizations, such as foundations, are different from private (profit) organizations. The difference lies in the organization's mechanism of obtaining the initial required resources, which are generally obtained from donations. Foundation assets can be obtained from nonbinding donations or assistance, waqf, grants, testamentary grants, and other acquisitions that do not conflict with the foundation's articles of association and/or applicable laws and regulations. Foundation resources come from donors who do not expect repayment or economic benefits commensurate with the amount of resources provided (Bastian, 2007). Nonbinding donations or assistance are donations or voluntary assistance received by foundations, both from the state, foreign aid, the community, or other parties that do not conflict with the applicable laws and regulations. While what is meant by "other income" is for example dividends, interest on bank savings, building rent, and income from the results of the foundation's operations.

\subsection{The Concept of Tithing According to the Bible}

God set tithes to be an obligatory offering. Tithing became a kind of mandatory tax introduced by Moses at God's command called the priesthood system and the sacrificial system. The decimal system in the time of the Mosaic Law can be classified into three sections as follows:

1. A tithe of all one's possessions given to the Levites for service in the Temple. In the Old Testament, tithing was a manifestation of God's way of caring for His servants who worked full time so they could not work to meet their own needs. In the Bible, Numbers $18: 21$, it is stated that:

"And to the children of Levi I have given as their heritage all the tenths offered in Israel, as payment for the work they do, the work of the Tent of meeting."

Tithe offerings as special offerings were intended for allowances or a kind of salary for the Levites and priests because of their duties in the Temple or the House of God, as well as the maintenance of the Temple. The Levites themselves were also not exempt from this obligation of tithing because they too had to give a tenth of what they got to High Priest Aaron as a special offering. In accordance with what is written in the book of Numbers 18:28 which reads:

"So you are to make an offering lifted up to the Lord from all the tenths which you get from the children of Israel, giving out of it the Lord's lifted offering to Aaron the priest."

Even though the tithe was given to the Levites, the offerings still belonged to God which He gave them, for God Himself had set the rules, not the Levites. 
This Levitical Priesthood is a form of representation of the work of Jesus Christ, whereby Jesus Christ as Melchizedek, who is the Great High Priesthood, receives tithes from Abraham, the ancestor of the Levites.

2. In addition, tithing is also for social purposes, namely for foreigners. orphans and widows in their midst.

"When you have taken out a tenth from the tenth of all your produce in the third year, which is the year when this has to be done, give it to the Levite, and the man from a strange land, and the child without a father, and the widow, so that they may have food in your towns and be full (Deuteronomy 26:12)."

3. Tithing is also used for temple maintenance mentioned in the Bible Malachi 3:10-11:

"Let your tenths come into the store-house so that there may be food in my house, and put me to the test by doing so, says the Lord of armies, and see if I do not make the windows of heaven open and send down such a blessing on you that there is no room for it. And on your account I will keep back the locusts from wasting the fruits of your land; and the fruit of your vine will not be dropped on the field before its time, says the Lord of armies."

A In the Bible, Matthew 23:23 states that:

"A curse is on you, scribes and Pharisees, false ones! for you make men give a tenth of all sorts of sweet-smelling plants, but you give no thought to the more important things of the law, righteousness, and mercy, and faith; but it is right for you to do these, and not to let the others be undone."

Finance is an important aspect of service that cannot be ignored. God's congregation must give because apart from services needing financial support, the poor and needy need attention. But the gift must be given voluntarily, without feeling forced. Giving these offerings is based on a sincere and loving heart.

\section{METHOD}

This research is a qualitative research with a phenomenological approach. Qualitative research is research that intends to understand the phenomenon of what is experienced by research subjects (Moleong, 2013). So that this approach will "lead" researchers to the perceptions of various communities about the meaning of church accountability in tithing offerings at the GKJW Church of the Lumajang Congregation.

Data collection in this study was carried out through 3 stages, including: a). interviews with informants, b). observation, c). documentation and other resources including the Bible and other Christian literature devoted to tithing offerings.

Next, qualitative data analysis is an analytical process consisting of three streams of activities that occur simultaneously, namely data reduction, data presentation, and drawing conclusions or verification.
The stages of data analysis in this study use the concepts given by Milas and Hubbreman, namely: a). data collection, namely data obtained from informants through interview techniques, b). Data reduction, namely data obtained in the field in very large quantities, for that researchers need to record carefully and summarize, sorting out which data is needed in research and discarding unnecessary ones. At this stage the data is reduced or eliminated because it is not directly related to the research focus. This is done with the aim of making it easier for researchers to present data systematically so that it is easy to understand, c). Data display (presentation of data). At this stage, after the data is reduced, the next step is to present the data in the form of brief descriptions, charts, relationships between categories and so on, d). Conclusion drawing/verification (draw conclusions). Drawing conclusions and verification is the final stage of the research. Conclusions are drawn after the data is reduced and has been presented with strong evidence.

\section{RESULT \& DISCUSSION}

The results of the description and meaning of accountability in the GKJW Church of the Lumajang Congregation provide an illustration that the practice of accountability in Church organizations has several dimensions, including:

\subsection{Accountability of Tithe Offerings as Belonging to God}

God is the owner of life, including the universe and humans as the image of his creation. "The Lord is the earth and all that is in it, and the world and those who live in it" (Psalm 24:1). With the above explanation, it is undeniable that God owns all the contents of the earth and the universe, including humans. Humans have absolutely no right to everything that was created and owned by God. In fact, humans are only managers (a manager) who is trusted by God to manage this universe. Humans are not the owner (Sabdono, 2018: 97). The whole life of the congregation, namely the family, assets, and businesses and work belongs to God. Everything must be dedicated to God under the guidance of the Holy Spirit. When a believer or congregation gives tithing, it is an act of returning God's property so that it becomes a stewardship, not a donation. This means that the Jama'at does not give to God, but "returns" what belongs to God. "For of him, and through him, and to him, are all things." (Romans 11:36a).

Based on his opinion, Mr. Totok Hari Cahyono in the following interview explained:

"Actually what we have received is actually not ours, everything is from God, so actually one hundred percent belongs to God, we work because God gave us life to give us health, if we are not given life we will not be given our health. We can't do anything because we can't do anything, so because we live it's God who gives life, we also work because of God." 
This is in line with the statement made by Mrs. Sri Wibowo in the following interview:

"All of our wealth actually belongs to God, God only asks us to return one tenth, we Christians, our guidelines are in the Bible, in the Bible it is in the book of Malachi. As for the $90 \%$, it actually also belongs to God, for that I use it according to God's will. Giving people what we need to give I also do when I can. My income is not only for the church, but for living and also for whom I want to give."

God reminds his people that all time, work, possessions, service, actually belongs to God. Therefore, giving an offering is an act of returning what belongs to God, so that it becomes a stewardship, not a donation or a gift.

\subsection{Accountability of Tithing As Acknowledgment That God Is the Source of Blessing}

Tithing is a joyful acknowledgment that all things come from God and the believer's act of honoring God as the owner and giver of all things. In giving tithes we use the blessings given by God according to His will. As stated by Mr. Totok Hari Cahyono in the interview as follows:

"By giving a tithe of the results we earn, we learn to remember that it is God who blesses our lives and that our lives belong solely to God. Tithing is part of what we receive, which we set aside and we return to God as a sign of acknowledgment that essentially all the treasures we have belong to God."

This is in line with the statement made by Mrs. Sri Wibowo in the following interview:

"All of our assets belong to God which was entrusted to us to be managed according to God's will and we are accountable to Him by returning a tenth of the income that God gave us."

Tithing is an act of returning God's property as a sign of acknowledgment that essentially everything we have comes solely from God. Thus the concept of acknowledgment and implementation of acknowledgment in the real actions that we do is the symbol of the recognition mark itself. Tithing is a concrete manifestation of our acknowledgment that without God's blessing we can do nothing.

\subsection{Accountability of Tithe Offerings as a Sign of Gratitude and Thank You}

Tithing offering is a form of response to God's goodness, every goodness, help, and salvation experienced, believed to come from God. Tithing is also an expression of gratitude for the salvation God has given us. However, tithing is not a condition for obtaining God's blessing, nor is the threat of intimidation providing the wrong motivation for tithing. We give because we love God, not because we fear punishment or because we expect something in return. Tithing is not a stimulus to stimulate God's goodness but a reaction to God's goodness. Tithing is not the tribute that God requires but the thanksgiving of the people who receive the blessing. We give tithing not so that we are blessed by God, but because we have been blessed by God.

As stated by Mr. Totok Hari Cahyono in the following interview:

"Essentially, the first tithe is that humans give thanks to God, the second is to give and share for others as taught by Jesus. By giving tithing, we acknowledge that we have received many blessings and favors from God."

This statement is supported by what Mrs. Sriwibowo said in the following interview:

"In my opinion, what we receive from God is what we must return to God. It is a blessing that God has given us. So from our income, we give $10 \%$ and then we bring it to church as our thanksgiving to God. Although sometimes when you think that giving $10 \%$ to God is too much, but that's what we have to do."

Therefore, tithing is not an obligation, but part of the blessings that are upon us, is returned to God in the form of a tithe offering as an expression of gratitude or thanks. Giving tithes joyfully is a form of response or response of believers to God's love and blessings that are so great for him.

\subsection{Accountability of Tithing As God's Command} In the Bible the Book of Malachi 3:10 which reads: "Let your tenths come into the store-house so that there may be food in my house, and put me to the test by doing so, says the Lord of armies, and see if I do not make the windows of heaven open and send down such a blessing on you that there is no room for it."

This verse mentions the commandment to bring the tithe to the house of the Lord. If we understand why we must tithe, then the act is neither a burden nor a torment but a joy to us. Tithing is God's way of blessing His people. Likewise, giving tithing is one of our ways to glorify God.

As stated by Mr. Totok Hari Cahyono that:

"The concept of tithing is an application of our Christian obligations to our faith, as it is written in the Bible that everything we have is from God, and we as administrators are given the task or command to administer it properly."

In line with what Mrs. Sri Wibowo said:

"All church teaching sources are from the Bible that the Bible teaches about tithing. Giving people what we need to give I also do when I can. My income is in addition to the church, to live and also to whom I want to give. In addition to learning to be honest and obedient, we are Christians, our guideline is in the Bible, in the Bible it is also in the Book of Malachi if we pay tithing it is to provide food supplies there. 
The practice of tithing is actually a priest's practice on the basis of the foremost law, namely, to love the Lord your God with all your heart and to love your neighbor as yourself. Faith without works is essentially dead, so the manifestation of our faith is shown by carrying out God's commands through actions, namely by giving tithes.

\subsection{Accountability of Tithe Offerings as an Manifestation of Honesty And Obedience to God's Commands}

As believers, it is proper for us to carry out God's commands as a concrete manifestation of our obedience to God's commands, as stated in the following interview with Mr. Totok Hari Cahyono:

"We are obliged to give a tenth of what blessings we get from God. But it must be distinguished if in the past there was no salary, if in modern times there is a job there is a salary. In ancient times the tithe was from agriculture, from sheep, from the spoils of war. Like the time of Abraham from the war results from one area both in the form of agriculture and sheep but not in the form of money. If today in the form of money. Depending on one's intentions if offering tithes from net or gross salary. If the salary is net for traders or food sales, the income is reduced by capital, some are sincere from gross or net income, if the salary is not paid for by selling services, they are paid for selling services. employees give one-tenth of salary. For example, if the salary is 5 million, the tithe is 500 thousand. A special tithe offering for presented in God's house, later he will offer other offerings, for example, apart from tithing offerings, later every worship service there will be 4 times of worship, if for example he wants to give other offerings, yes please. So basically tithing also tests our obedience to God's commands. Even though we have debts, we still have to give tithing. In the Bible, Malachi 3:8, which reads: "Will a man keep back from God what is right? But you have kept back what is mine. But you say, What have we kept back from you? Tenths and offerings. "So the tithe given is not based on our circumstances."

This statement is supported by what Mrs. Sriwibowo said in the following interview:

"By tithing we learn to be honest and obedient before God. The only way is to give one tenth of the work we receive, whether it's the results we get regularly or not. If the routine results I get from the pension every month. If it's not routine, I get the first from the results I sell ice cubes, we take the tithe, sell pulses I also take the tithe, sell anything I take the tithe. That's why the amount I offer in tithing also varies each month, depending on the income I get. In addition to learning to be honest and obedient, we are Christians, our guideline is in the Bible, in the Bible it is also in Malachi, if we pay tithing, it is to provide food supplies there. In my opinion, the tithe is put in the church, while if it is to give someone it is a mission offering."
The giving of tithes as evidence of the surrender of life in this case can be used as a lesson to fear God by bringing tithes to the temple of God. Tithing is a form of total obedience to Bible principles. The concept of stewardship and not ownership is the key to giving generously, sincerely, and with a clear purpose. More than our money or possessions, our obedience is more pleasing to God than our tithing. This does not mean that offering tithe is unimportant, but that it is not a large number or a beautiful and good offering but our hearts and obedience are more pleasing to Him.

\subsection{Accountability of Tithing As a Sign of Love Generosity \\ In offering tithes as a reminder that God has} already set an example in terms of giving. This was further conveyed by Mr. Totok Hari Cahyono in the following interview:

"Because God so loved us, God gave His only begotten Son so that we might not perish. The sacrifice of the Lord Jesus on the cross who was willing to give His life to atone for our sins as an expression of His love for us. Therefore, it is appropriate if we also give our tithe as a form of our love for God who was willing to sacrifice His life for us. What is the meaning of our money and possessions if we do not have life. Tithing is nothing compared to the sacrifice of Jesus Christ."

According to Mrs. Sriwibowo explained:

"Christ gave himself for us, suffered and sacrificed for us. Therefore, we also want to give and imitate Jesus by giving tithing as a form of our love for God and others."

Jesus Christ as our real example, has given teachings through His life. The sacrifice of Jesus is a sign of love and generosity for humans. Therefore, if we interpret the significance of the sacrifice of Jesus Christ itself, then the meaning of tithing as a sign of love and generosity is that we give tithe offerings which we will later distribute to others in need. Christians imitate the life of Jesus in the midst of the world, who was willing to give His life in service and become a blessing of life for humans. It simply departs from that love and generosity. Therefore, the real manifestation of love and generosity for others is to give tithing.

\subsection{Accountability of Tithing As a Sign of Faith Believe}

We believe that God provides for our needs and guarantees our future. That's why we don't have to worry about our future. By giving tithing we want to tell ourselves that we are not afraid of future shortages because God guarantees the future. Tithing is a sign of our faith in God's future providence. According to Mr. Totok Hari Cahyono in the following interview:

"Even if our salary or income is calculated to be less, we still have to offer tithing. Even though we have debts, we must still give tithing. What happens is in accordance with what we believe, if we are worried that 
we will be lacking, that is what will happen. On the other hand, if we believe and believe that God will provide what we need, then that will also happen. By giving tithing, we actually want to train ourselves to keep faith in God. We believe that God provides for our needs and guarantees our future. That's why we don't need to worry."

Furthermore, Mrs. Sriwibowo also said:

"Although I am not abundant, but life is quite happy. As long as I was around, according to God's plan for my life, I learned to be honest by offering tithing. Besides that I also pray, read the word, listen to sermons. There are some church members who also routinely give tithing, work modestly, earn a modest salary, dare to give tithing. Giving tithing is not because of courage or not but because of intention and understanding of the verses in the Bible."

That's why we give tithing not only in times of abundance but also in times of need, not only when we are rich but also when we are poor. Sometimes we give tithing with feelings of anxiety or fear, this can happen for various reasons, whether it's because of the need for economics in our many lives which causes these fears to enter our minds. In Matthew 6:31-33 it says that:

"Then do not be full of care, saying, What are we to have for food or drink? or, With what may we be clothed?. Because the Gentiles go in search of all these things: for your Father in heaven has knowledge that you have need of all these things: But let your first care be for his kingdom and his righteousness; and all these other things will be given to you in addition."

This Bible verse provides a reinforcement for us about the meaning and significance of the tithe offering itself to express our faith and trust in God's providence in our lives that we will still be given abundance by God in God's riches.

\subsection{Accountability of Tithing As a Responsibility Against the Church}

Based on the word of God in Malachi 3:10 which reads:

"Let your tenths come into the store-house so that there may be food in my house, and put me to the test by doing so, says the Lord of armies, and see if I do not make the windows of heaven open and send down such a blessing on you that there is no room for it."

Based on this verse, Rev. Johni Sukohadi said:

"In the verse it is said that we bring our tithe offering to the treasury house which can be interpreted as "Church" to be managed properly."

Mr. Ezra Imam Kurdi as Treasurer of the Jama'at added: "To fulfill the needs of the pastor's life, it has also been regulated in the GKJW system that because he has given his life to work in God's Church full time, the pastor has the right to get the fulfillment of his life needs from the blessings received by the church. The living needs of Pastor GKJW and his family mainly include costs and or materials for food and clothing, official housing, lighting and water facilities, opportunities and costs for maintaining health and physical fitness, including time and costs for leave, opportunities and facilities to increase knowledge and broaden horizons. also old age guarantee. The implementation of fulfilling the needs of the Pastor's life which is the responsibility of the church is regulated in its own regulations."

This statement agrees with what Mr. Totok Hari Cahyono said in the following interview:

"Pastors who serve full time for the church also have needs as humans and also for their families, so it is the church's obligation to meet the needs of pastors and their families. Also for church ministers who are fulltime or full-time also need financial support from the church to meet the needs of themselves and their families. It can be met from the tithing we bring to church."

Added by Mrs. Sriwibowo:

"Based on what is written in the Bible Malachi 3:10a it is stated that Bring the entire tithe into the storehouse so that there is a supply of food in my house and put me to the test. So our job is to give a tithe to the church."

Jesus demanded great sacrifices from His followers in the past, even to the point of giving their lives for Him. Contributing tithing to help build His church today is at least the same as giving life in the context of Jesus' time. However, the tithe that is given or brought to the church is only limited to the temporary ownership of the church institutionally, which must then be allocated to those who need tithe offerings. This is based on the understanding of sacrifice for Jesus. Jesus has set an example of wholehearted service as a servant. And if we explore further about the ministry of the Lord Jesus, we will find some very principled things for us to emulate. That the true life of service is how we serve others, and one of the real manifestations is the Christian life as a living church is to give tithes through the church, which will then be distributed properly and correctly by the church to those who are entitled to receive or receive it.

\subsection{Accountability of Tithing As a Responsibility Social}

Tithe offerings also have other meanings apart from the meaning of belonging to God in them, another meaning that is the existence of a social responsibility in them. Related to that, Rev. Johny Sukohadi gave an understanding contained in the Book of Deuteronomy 26:12 which reads:

"When you have taken out a tenth from the tenth of all your produce in the third year, which is the year when this has to be done, give it to the Levite, and the man from a strange land, and the child without a father, and the widow, so that they may have food in your towns and be full;", 
"So the responsibility given to humans is not only responsibility to God but also responsibility to fellow human beings."

This is in line with what was conveyed by Mrs. Sriwibowo:

"Giving people what we need to give is also what I do when I can. My income is not only for the church, but for living and also for whom I want to give."

This responsibility requires humans to be able to manage existing finances so that there are no deviations that lead to errors in the amount that must be returned later.

\subsection{Accountability of Tithe Offerings as a Form Faith in the Church}

The GKJW institution states that every adult citizen has the obligation and responsibility to share in carrying out the needs of the church, in this case this is manifested by giving tithing offerings. Members of the congregation bring their tithe to the Lord's house or church as a form of belief in the church that they are sowing in the right place. Delivered by Mr. Totok Hari Cahyono in the interview as follows:

"We take our tithe to a place we are sure to sow in the right place, such as a church. Where we are sure that our tithe offering will be managed properly according to God's will. Even if it is misused, it is their responsibility to God, the important thing is that we have done our part by giving tithes in accordance with God's commandments."

Sri Wibowo's mother also conveyed the same thing: "My intention is to give tithe through the church, the management is God's business with them, the most important thing is my intention to offer it to God through the church. There are several churches whose tithes are handed over and managed by the pastor himself, but in GKJW the tithe is offered and managed by the church. Even though it was handed over to the church, the church actively gave it to anyone in need. The truth is that the tithe is given in the church and then the church distributes it to those the church deems necessary, the elderly, the poor."

In accordance with the GKJW system, the church's financial management must first place money and other assets according to a messianic function, namely as a tool to express love and service to fellow human beings, at the same time as a tool to carry out missions and glorify God.

\section{CONCLUSION}

This study aims to examine more deeply the meaning of tithing accountability as a form of accountability for the members of the GKJW Church Lumajang congregation, to God as the head of the church. The results of the meaning of the practice of accountability for tithe offerings are interpreted differently in the organization of the Lumajang GKJW Church.

First, as God's. The practice of accountability for tithe offerings as God's property in the GKJW Church of the Lumajang Congregation, is carried out entirely by the congregation by believing that the tithe offering belongs to God.

Second, as a sign of recognition. By giving a tithe, the congregation confesses that body, soul and spirit and all things come from God. Thus the act of giving tithing is a symbol of the sign of confession itself.

Third, as a sign of gratitude and thanks. Tithing is a form of response to God's goodness. Thus, tithing is not a tribute or an offering to stimulate God's goodness. By giving a tithe, the congregation acknowledges that they have received God's goodness and mercy, so some of it is returned to God in the form of a tithe offering as an expression of gratitude and thanks.

Fourth, as a command of God. Tithing is actually a priestly practice on the basis of the foremost law, namely, to love the Lord your God with all your heart and to love your neighbor as yourself. Faith without works is essentially dead, so the manifestation of our faith is shown by carrying out God's commands through actions, namely by giving tithes.

Fifth, as a form of honesty and obedience. Tithing is an act of an honest heart and is obedient to God's commandments. It is not such a large amount to the Lord that $\mathrm{He}$ is amazed by our tithing. Because it is important to remember that God is the God who created the heavens and the earth and everything in it. He owns this universe. So it's not our money that He wants, but our honest heart and obedience that is more pleasing to Him.

Sixth, as a sign of love and generosity. Basically giving tithing is a manifestation of the act of love itself. This is in line with the main law, namely in Matthew 22:37 which reads "Jesus answered him: 'Love the Lord your God with all your heart and with all your soul and with all your mind."' generosity to others is to give tithing.

Seventh, as a sign of faith and trust. The congregation believes and believes that God will provide for all needs and guarantee the future. By giving a tithe, you are not afraid of future shortages because God guarantees the future. Tithing is a sign of faith and trust in the congregation in God's future providence.

Eighth, as a responsibility to the church. God's church needs support from believers, especially church 
members to contribute to God's work, one of which is by giving tithes. So in this case the tithe is given to the church as the congregation's contribution to support the church's ministry and for the welfare of God's servants who have given their lives for spiritual service.

Ninth, as social responsibility. Tithing also has the meaning of love for others, and this is evidenced by giving tithes to people in need, caring to share, sharing wealth fairly, and helping to lighten the burden of others.

Tenth, as a form of belief in the church. That the church will administer the tithe offering according to God's will. Manage finances properly, openly, honestly and fairly. In accordance with the GKJW system, the church's financial management must first place money and other assets according to a messianic function, namely as a tool to express love and service to fellow human beings, at the same time as a tool to carry out missions and glorify God.

\section{SUGGESTION}

Based on the research that has been done, there are suggestions that can be given by researchers to further researchers to conduct more in-depth research, both in terms of interviews with informants and processing data with more references, even the object of research can be expanded at the Regional Council or Supreme Council level. to compare the accountability of tithing offerings.

\section{REFERENCES}

- Alkitab. (2014. Lembaga Alkitab Indonesia. Jakarta.

- Pelayan Harian Majelis Agung GKJW. (1996). Tata Dan Pranata GKJW dan Peraturan Majelis Agung Tentang Badan-Badan Pembantu Majelis. Malang.

- Dewi, Atmadja, dan Adiputra. (2015). Konsep Akuntabilitas Keuangan Dalam Organisasi Keagamaan (Studi Kasus Pada Gereja Kerasulan Baru Di Indonesia, Distrik Jawa Timur dan Bali). e-Journal S1. Universitas Pendidikan Ganesha Jurusan Akuntansi Program S1. Volume 3, No. 1, Tahun 2015.

- Randa, F. (2010). Akuntabilitas Kepemimpinan Dalam Organisasi Keagamaan (Studi Etnografi Pada Sebuah Gereja Katolik Di Tana Toraja). Jurnal Sistem Informasi Manajemen dan Akuntansi, Volume 8, Nomor 2, Oktober 2010, 2552. Fakultas Ekonomi UAJ Makasar.

- Randa, Fransiskus, dkk. (2011). Studi Etnografi: Akuntabilitas Spiritual Pada Organisasi Gereja Katolik Yang Terinkulturasi Budaya Lokal. Jurnal
Akuntansi Multiparadigma, Volume 2, Nomor 1, Tahun 2011.

- Randa, F. (2011). Akuntabilitas Keuangan Dalam Organisasi Keagamaan (Studi Etnografi Pada Sebuah Gereja Katolik Di Tana Toraja). Jurnal Sistem Informasi Manajemen dan Akuntansi, Volume 9, Nomor 2, Oktober 2011, 59-83. Fakultas Ekonomi UAJ Makasar.

- Randa, F. (2011). Rekonstruksi Konsep Akuntabilitas Organisasi Gereja: Studi Etnografi Kritis Inkulturatif Pada Gereja Katolik di Tana Toraja. Simposium Nasional Akuntansi XIV Aceh, 2011.

- Silvia, Janets dan Muhammad Ansar. (2011). Akuntabilitas Dalam Perspektif Gereja Protestan: Studi Fenomenologis Pada Gereja Protestan Indonesia Donggala Jemaat Manunggal Palu. Simposium Nasional Akuntansi XIV Aceh, 2011.

- Patty, Agustina Christina dan Gugus Irianto. (2013). Akuntabilitas Persepuluhan Gereja. Jurnal Akuntansi Multiparadigma, 4(2).

- Sitanggang, M. (2011). Teori Biblika Mengenai Perpuluhan. Veritas Jurnal Teologi dan Pelayanan, Volume 12, No. 1, April 2011, 19-37. Universitas Jember.

- Nur Indriantoro dan Bambang Supomo. (1999). Metode Penelitian Bisnis Untuk Akuntansi \& Manajemen. Penerbit BPFE-Yogyakarta. Yogyakarta.

- M Djunaidi Ghony dan Fauzan Almanshur. (2016). Metode Penelitian Kualitatif. Penerbit Ar-Ruzz Media. Jogjakarta.

- Sugiyono. (2012). Metode Penelitian Kuantitatif, Kualitatif, dan R\&D. Penerbit Alfabeta. Bandung.

- Creswell, John W. 2013. Research Design Pendekatan Penelitian Kualitatif, Kuantitatif, dan Mixed. Penerbit Pustaka Pelajar. Yogyakarta.

- Mardiasmo. (2018). Akuntansi Sektor Publik. Penerbit ANDI. Yogjakarta.[15]Indra Bastian. 2007. Akuntansi Yayasan dan Lembaga Publik. Penerbit Erlangga. Jakarta.

- Erastus, S. (2018). Perpuluhan. Penerbit Rehobot Literature. Jakarta.

- Steven, T. (2008). Persepuluhan: Kunci Kebenasan Financial. Penerbit ANDI. Yogjakarta.

- Yamowa'a, B. (2009). Mengungkap Misteri Persepuluhan. Penerbit ANDI. Yogjakarta.

- Petrus, A. P. (2016). Covenant Money. Penerbit Media Injil Kerajaan. Semarang.

- Ronny, S. (2015). Persepuluhan Milik Siapa. Penerbit Majesty Publishing. Jakarta.

- John, A. (2002). Apakah Perpuluhan dan Persembahan itu sama?. Penerbit Media Injil Kerajaan. Semarang. 